\title{
Cancer incidence among workers in the Norwegian ferroalloy industry
}

\author{
H KJUUS, ${ }^{1}$ A ANDERSEN, ${ }^{2}$ S LANGÅRD, ${ }^{1}$ AND K E KNUDSEN ${ }^{3}$ \\ From the Department of Occupational Medicine, ${ }^{1}$ Telemark Sentralsjukehus, $N-3900$ Porsgrunn, the Cancer \\ Registry of Norway, ${ }^{2}$ Montebello, Oslo 3, and the Health Board of the Norwegian Ferroalloy Industry, ${ }^{3}$ Fiskaa \\ Verk, Kristiansand S, Norway
}

ABSTRACT The total mortality and the incidence of cancer was studied among a cohort of employees at the six oldest ferrosilicon and ferromanganese plants in Norway. The cohort consisted of 6494 men employed for more than 18 months before 1970 and has been followed up from 1953 to 1982. The standardised incidence ratio (SIR) for cancer (all sites) was 0.94. The observed number of cancers was as expected for lung cancer (SIR = 0.99) and for most of the other cancer sites studied. A statistically significant reduction of stomach cancer was found (SIR $=0.72)$. There was an increased incidence of lung cancer (SIR $=1 \cdot 75)$ and cancer of the prostate $(S I R=1 \cdot 56)$ in the workers at one ferrosilicon plant and of colonic cancer $(\mathrm{SIR}=1.90)$ at another ferrosilicon plant.

Ferroalloys are alloys of iron and another metal, most commonly chromium, manganese, or silicon. They are used as a vehicle for introducing specific elements into the manufacture of steel in order to produce steel with specific properties. Ferrochromium is used in converting steel to stainless steel. Ferromanganese imparts strength, toughness, and hardness to steel and the ferrosilicons act mainly as "metal cleaners" by removing oxygen from the molten steel.

The emissions from the ferroalloy production processes consist of a complex mixture of particles, fumes, and chemicals, depending on which alloy is produced. $^{12}$ The electrothermal reduction of iron containing ores with carbon as the reduction agent, however, is common to the whole industry. Irrespective of the alloy produced, the ferroalloy process implies exposure to combustion products, among which the polycyclic aromatic hydrocarbons (PAH) are considered to be of particular interest for human health.

The production of ferroalloys is an energy consuming process, and Norway has the advantage of easy access to hydroelectric power. Of the 50 ferroalloy plants in Western Europe, 14 are located in Norway. With approximately $10 \%$ of the world production, Norway is an important ferroalloy producer. Today these 14 plants produce 1070000 tons of ferroalloys a year and employ 5000 workers.

As to the possible health hazards associated with Accepted 1 July 1985 the production of ferroalloys, silicosis due to exposure to crystalline and amorphous silica has been noted, ${ }^{34}$ as has manganese poisoning, with Parkinson like symptoms, among employees producing manganese alloys. ${ }^{56}$

In regard to exposure to known carcinogens in the ferroalloy industry, asbestos has been regularly used in the maintenance of the furnaces. The production of ferrochromium has also been the object of particular interest, and epidemiological studies in ferrochromium plants in Norway and Sweden have shown an excess of lung cancer associated with exposure to ferrochromium ${ }^{7}$ and asbestos related maintenance work. ${ }^{8}$ There are, however, epidemiological studies of cancer in workers producing ferroalloys other than ferrochromium ${ }^{7}$ (J Alexander et al, paper given at XX International Conference on Occupational Health, Cairo, 1981).

In 1973-5 a pilot project on the incidence of cancer among employees from three Norwegian ferroalloy plants was performed in cooperation with the Norwegian Cancer Registry. No excess of lung cancer was shown in this study ( 8 cases observed against 8.8 expected) but a possible excess of urogenital cancer was observed.

In the light of this finding the Health Board of the Norwegian Ferroalloy Industry initiated an epidemiological study comprising all ferroalloy plants in Norway, and we present the results from the six oldest plants. 
Table 1 Characterisation of the subcohorts

\begin{tabular}{|c|c|c|c|c|}
\hline Plant & Year of production start & Main production & Personal records available from & $\begin{array}{l}\text { Start of subcohorts } \\
\text { (persons employed) }\end{array}$ \\
\hline $\begin{array}{l}\mathbf{A} \\
\mathbf{B} \\
\mathbf{C} \\
\mathrm{D} \\
\mathrm{E} \\
\mathrm{F}\end{array}$ & $\begin{array}{l}1918 \\
1910 \\
1907 \\
1910 \\
1915 \\
1923\end{array}$ & $\begin{array}{l}\text { FeSi, Si-metal, anode paste } \\
\text { FeSi } \\
\text { FeSi, calcium carbide } \\
\text { FeMn, SiMn } \\
\text { FeMn, FeSi } \\
\text { FeMn, SiMn }\end{array}$ & $\begin{array}{l}1918 \\
1910 \\
1920 \\
1912 \\
1915 \\
1915\end{array}$ & $\begin{array}{l}\text { From } 1918 \\
\text { From } 1910 \\
\text { In } 1930 \\
\text { From } 1930 \\
\text { From } 1915 \\
\text { From } 1923\end{array}$ \\
\hline
\end{tabular}

\section{Production process}

Table 1 gives a historical summary of the major products manufactured at the six study plants. Plants A, $\mathrm{B}$, and $\mathrm{C}$ have mainly produced ferrosilicon ( $\mathrm{FeSi})$ and silicon metal (Si-metal), with additional production of calcium carbide at plant $\mathrm{C}$ in previous years. Plants $\mathrm{D}$ and $\mathrm{E}$ have traditionally produced ferromanganese (FeMn) and silicomanganese (SiMn) in combination with $\mathrm{FeSi}$; plant $\mathrm{F}$ has produced only manganese alloys.

All plants have used the Söderberg electrode, which consists of calcinated anthracite and a binder of tar and pitch. For the production of Si-metal, prebaked carbon electrodes have been used. In the early years of production several plants produced their own electrode paste, but for the past 15 years plant $A$ has produced anode paste for the other plants. FeSi has been produced in open ovens for the whole study period, while the ferromanganese ovens were gradually enclosed from 1953 onwards. In the past decade specific alloys have been produced continuously in the same furnaces, but previously any furnace could be used to produce any other alloy as required.

$\mathrm{FeSi}$ has been made mainly from quartz and scrap metal or forge scales, with coke or coal as the reduction agent. It is produced in different grades according to the content of silicon $(45 \%, 75 \%$, and $90 \%)$, and the alloy usually contains low amounts of calcium, magnesium, phosphorus, and aluminium. FeSi must remain dry during storage and transport, as contact with moisture leads to the formation of phosphine and arsine. In earlier years several deaths occurred from phosphine/arsine intoxication on ships transporting ferrosilicon from ferroalloy plants. ${ }^{9}$

FeMn, which contains $78-90 \%$ manganese, is made from manganese containing ores and coke, with quartz and limestone as slag producers. The slag is used as a raw material for the production of SiMn, by which the manganese content is increased from $80 \%$ to $90 \%$. Crushing and sieving of the castings were mainly performed by hand before $1955-60$ and there is still some manual sorting of manganese alloys.

\section{Measurements of dust levels}

During the past 30 years, the change from manual to machine handling of raw materials and alloys, together with the enclosure of furnaces and improved ventilation, have rradually reduced the individual worker's exposus io dust and fumes. The concentrations of dust in the working atmosphere in previous years are not known, as valid measurements have been performed only during the past 15 years. Even so, a substantial part of the measurements in several of the plants around 1970 indicates mean concentrations of total dust higher than $5 \mathrm{mg} / \mathrm{m}^{3}$, with many values between 10 and $30 \mathrm{mg} / \mathrm{m}^{3}$. The proportion of dust particles with diameter below $5 \mu \mathrm{m}$ has been measured as $25-65 \%$ by weight.

Manganese dust measurements at plant $F$ in 1979 were between 0.5 and $2 \mathrm{mg} / \mathrm{m}^{3}$. Only a few measurements of PAH have been performed in connection with the preparation of tapping spouts at the furnaces. These sporadic measurements, which have been in the range of 3-49 $\mu \mathrm{g} / \mathrm{m}^{3}\left(10 \mu \mathrm{g} / \mathrm{m}^{3}\right.$ TWA), indicate that the PAH exposure in the study plants has been substantially lower than in coke plants, ${ }^{10}$ and also lower than that reported from the Norwegian aluminium industry, ${ }^{11}$ which also makes use of the Söderberg electrode.

In previous years asbestos has been regularly used at the plants, mainly by the maintenance staff, for heat protection and insulation around the furnaces. The amount used before 1965 is not known but in 1965-75 a mean consumption of $5000 \mathrm{~kg} /$ year/plant has been estimated. Altogether in 1981 the Norwegian ferroalloy industry used 25 tons of asbestos, of which 15 tons were used around the furnaces.

\section{Material and methods}

MATERIAL

The initial purpose of the project was to study the incidence of cancer in all the 14 Norwegian ferroalloy plants. Two plants producing ferrochromium and ferrovanadium had recently been subjected to separate 


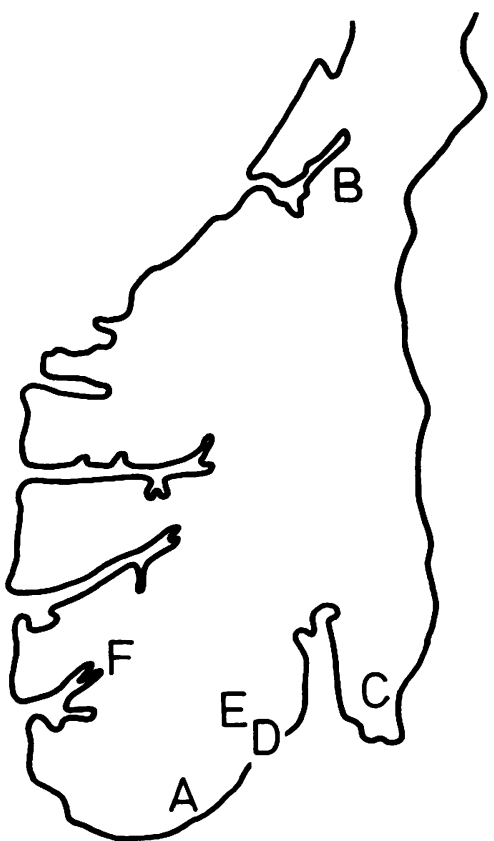

Location of the six study plants in southern Norway.

epidemiological studies ${ }^{7}$ (J Alexander, Cairo conference) and were not included in this study. One plant was also excluded because it was not possible to obtain complete information on former employees. Five of the plants established after 1960 were also omitted from this part of the project owing to the short follow up period. The present study, therefore, relates to the six oldest ferroalloy plants in Norway, all established before 1920. Plants A, C, D, and E are in small towns and plants $B$ and $F$ in rural areas of southern Norway (figure).

The plants provided information on former employees as far back as possible. As the oldest segment of a cohort is particularly vulnerable to outcome selective drop out, an individual starting date for each subcohort was chosen, from the time at which the personnel register at the plant was considered to be complete. Initially some plants provided information of former employees back to the 1950s only. By going back to older archives and personnel registers at the plants, old "cohort segments" were added to the initial subcohorts, making many of them complete from the year production started. Table 1 gives the starting date for each subcohort, varying from 1910 to 1930 . Five of the subcohorts have been formed as inception cohorts, with workers employed from a certain date, whereas the subcohort from plant $\mathrm{C}$ may be considered as a cross sectional cohort, ${ }^{1213}$ as it is based on a personal register of persons employed in 1930 and later.

\section{METHODS}

Since 1 January 1953 all new cases of cancer in Norway have been recorded by the Cancer Registry of Norway. This registration is based on compulsory reporting by hospital departments and histopathological laboratories and on death certificates reported by the Central Bureau of Statistics.

In 1960 all individuals in Norway were given a personal identification number, which has since been given to all inhabitants at birth or at immigration. Those in the cohort who developed cancer in the observation period were identified in the cancer registry by this personal identification number. For 1953-60 the identification of the cases of cancer had to be done manually, whereas since 1960 this matching of the cases of cancer has been fully automated.

On the personnel lists provided by the plants about 6500 had no personal identification numbers. Most of these were traced through different sources, leaving 742 or $6 \%$ of the total cohort unidentified by personal identification number. Most of these came from the oldest segment of the cohort, whereas wrong date of birth or mis-spelled names could be other reasons for failing to identify them.

Of the 11921 workers available for the study, all 416 women were excluded, together with the 742 unidentified and 21 with incomplete employment data. The 4248 workers employed after 1 January 1970 or for a shorter period than 18 months were also excluded, leaving a final study cohort of 6494 (table 2).

The observation period for the cohort was 30 years, from 1953 to the end of 1982. All those alive in 1953 were observed for occurrence of cancer from that year to the year of death or to the end of the observation period. Those employed later than 1953 were considered "under observation" from the middle of the year they were first employed.

Table 2 Summary of the formation of the cohort, employees from all six plants

\begin{tabular}{lrr}
\hline & & No \\
\hline Initial number of personal records: & 1610 & \\
$\quad$ Duplicates & 416 & \\
Women & 742 & \\
Unidentified men & 21 & \\
Incomplete employment data & 4248 & \\
Employed after 1 January 1970 or less & & \\
$\quad$ than 18 months & & 6494 \\
Ultimate cohort & & \\
\hline
\end{tabular}


The observed number of cases of cancer in the cohort was compared with the incidence of cancer of the total male Norwegian population. The five year age specific incidence rates for each year 1953-82 was used for this comparison. Standardised mortality ratios (SMRs) have been computed for overall mortality and standardised incidence ratios (SIRs) for selected cancer sites. For observed values $<100$, the deviation of an SIR from 1.00 was tested assuming a Poisson distribution for the observed number of cancer cases, using a two sided test of significance. For observed values $\geqslant 100$, two sided $p$ values have been based on the usual large sample chi-square statistic $\left(\chi^{2}=(\mathrm{O}-\mathrm{E})^{2} / \mathrm{E}\right)$ with test based $95 \%$ confidence intervals $(95 \% \mathrm{CI})$, as suggested by Miettinen. ${ }^{14}$

\section{OCCUPATIONAL CATEGORIES}

Each plant used its own personnel register to compile a list of all employment periods for present and former employees with employment time exceeding six months. The total number of years employed was then calculated for each person. For those classified as "working at present" at the time the lists were completed (1977), employment time was calculated up to 31 December 1981 or to the time of retirement (67 years).

Job characterisation for each worker was based on information from three different sources. The main source was the personnel list from the plants, which provided information on the place of work within the plant, or occupational title for the longest job held at the plant. Some plants gave detailed information on the different tasks performed by each individual worker, whereas most plants provided information only on the main occupational title or place of work for the job held longest at the working plant. Information on job title or place of work was lacking for about $10 \%$ of the former employees. Experienced people from the personnel departments together with retired worker "veterans" managed to identify job title or main place of work for most of these. The occupational health service at the plants could give additional information from old health records on the place of work for some of the workers. Altogether 217 workers, or $3 \%$ of the cohort, could not be identified by job title or main place of work. Most of these workers had been employed for shorter periods in the 1920 s and 1930s.

Ten different occupational categories were defined. In general, the classification was made according to the place of work where the person had worked the longest time. If he had been working 10 years or more at the furnaces, however, he was classified as "furnace worker" irrespective of other jobs of longer duration. In one subcohort (plant F) information about the type of maintenance work performed was not available. All 337 maintenance workers from this plant have therefore been allocated to the occupational category "maintenance, other."

Interchange of workers between FeMn production and $\mathrm{FeSi}$ production was common in previous years at the two plants producing both alloys (plants D and E). Thus, except for a small subcohort producing FeMn at plant E after 1963, it was not possible to distinguish between those who had been working mainly in the FeMn production and FeSi production respectively.

\section{Results}

Table 3 shows the distribution of the men and the person-years in the cohort by plant together with the total mortality during the observation period. Among 6494 men there were 1935 deaths from all causes compared with $2150 \cdot 3$ expected. The overall SMR was 0.90 , varying from 0.82 to 1.01 between the plant subcohorts.

In 1953-82 634 new cases of cancer were observed against 674.1 cases expected, which gives a SIR of 0.94 (table 4). There was no statistically significant excess of any of the cancers under study. The highest SIR observed was for sinonasal cancer (based on 5 observed cases and 2.7 expected) and for malignant melanoma $(\mathrm{O} / \mathrm{E}=18 / 14 \cdot 6)$; neither of these results

Table 3 Observed and expected total mortality among employees at six ferroalloy plants during the follow up period, 1953-82

\begin{tabular}{|c|c|c|c|c|c|c|}
\hline \multirow[t]{2}{*}{ Plant } & \multirow{2}{*}{$\begin{array}{l}\text { No } \\
\text { employed }\end{array}$} & \multicolumn{5}{|c|}{ Total mortality } \\
\hline & & Observed & Expected & $S M R \dagger$ & $95 \% C I \ddagger$ & Person-years \\
\hline $\begin{array}{l}\mathbf{A} \\
\mathbf{B} \\
\mathbf{C} \\
\mathbf{D} \\
\mathbf{E} \\
\mathbf{F}\end{array}$ & $\begin{array}{r}983 \\
918 \\
632 \\
773 \\
1161 \\
2027\end{array}$ & $\begin{array}{l}242 \\
303 \\
292 \\
248 \\
241 \\
609\end{array}$ & $\begin{array}{l}245 \cdot 3 \\
367 \cdot 6 \\
290 \cdot 2 \\
254 \cdot 8 \\
282 \cdot 8 \\
709 \cdot 6\end{array}$ & $\begin{array}{l}0.99 \\
0.82^{* *} \\
1.01 \\
0.97 \\
0.85^{*} \\
0.86^{* *}\end{array}$ & $\begin{array}{l}(0.87-1.12) \\
(0.73-0.92) \\
(0.89-1.13) \\
(0.86-1.10) \\
(0.75-0.97) \\
(0.79-0.93)\end{array}$ & $\begin{array}{l}22263 \\
21966 \\
13658 \\
17378 \\
26730 \\
49679\end{array}$ \\
\hline Total & 6494 & 1935 & $2150 \cdot 3$ & $0.90^{* *}$ & $(0.86-0.94)$ & 151674 \\
\hline \multicolumn{7}{|c|}{$\begin{array}{l}* p<0.05, * * p<0.01 \\
+ \text { Standardised mortality ratio. } \\
\$ 95 \% \text { confidence interval. }\end{array}$} \\
\hline
\end{tabular}


Table 4 Observed and expected number of selected types of cancer among 6494 employees at six ferroalloy plants, $1953-82$

\begin{tabular}{|c|c|c|c|c|}
\hline Cancer site (ICD, 8th revision) & Observed & Expected & SIR & $95 \% C I$ \\
\hline $\begin{array}{l}\text { Stomach (151) } \\
\text { Colon (153) } \\
\text { Rectum (154) } \\
\text { Pancreas (157) } \\
\text { Sinonasal (160) } \\
\text { Lung (162, 163) } \\
\text { Malignant melanoma (172) } \\
\text { Prostate (185) } \\
\text { Bladder (188) } \\
\text { Kidney (189) } \\
\text { Brain (191) } \\
\text { Leukaemia (204-207) } \\
\text { Other sites }\end{array}$ & $\begin{array}{r}64 \\
56 \\
35 \\
28 \\
5 \\
77 \\
18 \\
125 \\
34 \\
21 \\
8 \\
15 \\
148\end{array}$ & $\begin{array}{r}89 \cdot 0 \\
50 \cdot 6 \\
32 \cdot 7 \\
27 \cdot 3 \\
2 \cdot 7 \\
77 \cdot 7 \\
14 \cdot 6 \\
125 \cdot 8 \\
38 \cdot 3 \\
23 \cdot 3 \\
13 \cdot 4 \\
19 \cdot 9 \\
158 \cdot 8\end{array}$ & $\begin{array}{l}0.72 * \\
1.11 \\
1.07 \\
1.03 \\
1.85 \\
0.99 \\
1.23 \\
0.99 \\
0.89 \\
0.90 \\
0.60 \\
0.75 \\
0.93\end{array}$ & $\begin{array}{l}(0.55-0.92) \\
(0.84-1.44) \\
(0.75-1.49) \\
(0.68-1.48) \\
(0.59-4.33) \\
(0.78-1.24) \\
(0.73-1.95) \\
(0.75-1.31) \\
(0.62-1.24) \\
(0.56-1.38) \\
(0.26-1.18) \\
(0.42-1.24) \\
(0.79-1.10)\end{array}$ \\
\hline All cancer $(140-209)$ & 634 & $674 \cdot 1$ & 0.94 & $(0.87-1.02)$ \\
\hline
\end{tabular}

*p<0.01.

Table 5 Observed $(O)$ and expected (E) cases of cancer among employees at each of the six ferroalloy plants, 1953-82, by plant

\begin{tabular}{|c|c|c|c|c|c|c|c|c|c|c|c|c|}
\hline \multirow[t]{3}{*}{ Plant } & \multicolumn{10}{|c|}{ Cancer sites } & \multirow[t]{3}{*}{$S I R$} & \multirow[t]{3}{*}{$95 \% \mathrm{Cl}$} \\
\hline & \multicolumn{2}{|c|}{$\begin{array}{l}\text { Lung } \\
(I C D 162,163)\end{array}$} & \multicolumn{2}{|c|}{$\begin{array}{l}\text { Stomach } \\
(I C D \text { I5I) }\end{array}$} & \multicolumn{2}{|c|}{$\begin{array}{l}\text { Colon } \\
\text { (ICD 153) }\end{array}$} & \multicolumn{2}{|c|}{$\begin{array}{l}\text { Prostate } \\
\text { (ICD I85) }\end{array}$} & \multicolumn{2}{|c|}{$\begin{array}{l}\text { All sites } \\
(I C D \text { 140-209) }\end{array}$} & & \\
\hline & $O$ & $E$ & $O$ & $E$ & $O$ & $E$ & $O$ & $E$ & $O$ & $E$ & & \\
\hline $\begin{array}{l}\text { A } \\
\text { B } \\
\text { C } \\
\text { D } \\
\text { E } \\
\text { F }\end{array}$ & $\begin{array}{r}17 \\
9 \\
12 \\
9 \\
10 \\
20\end{array}$ & $\begin{array}{r}9 \cdot 7^{*} \\
13 \cdot 1 \\
8 \cdot 7 \\
9 \cdot 3 \\
11 \cdot 7 \\
25 \cdot 2\end{array}$ & $\begin{array}{r}6 \\
14 \\
7 \\
6 \\
8 \\
23\end{array}$ & $\begin{array}{l}9.8 \\
16.0 \\
11.2 \\
10.3 \\
11.6 \\
30.1\end{array}$ & $\begin{array}{r}5 \\
12 \\
11 \\
9 \\
5 \\
14\end{array}$ & $\begin{array}{c}5 \cdot 8 \\
8 \cdot 9 \\
5 \cdot 8^{*} \\
5 \cdot 9 \\
7 \cdot 1 \\
17 \cdot 1\end{array}$ & $\begin{array}{r}20 \\
23 \\
14 \\
10 \\
9 \\
49\end{array}$ & $\begin{array}{l}12 \cdot 8^{*} \\
23 \cdot 3 \\
15 \cdot 6 \\
14 \cdot 4 \\
16 \cdot 2 \\
43 \cdot 5\end{array}$ & $\begin{array}{r}98 \\
100 \\
83 \\
68 \\
77 \\
208\end{array}$ & $\begin{array}{r}78.5 \\
117.6 \\
78.7 \\
78.6 \\
95.1 \\
225.6\end{array}$ & $\begin{array}{l}1.25^{*} \\
0.85 \\
1.06 \\
0.87 \\
0.81 \\
0.92\end{array}$ & $\begin{array}{l}(1.01-1.52) \\
(0.69-1.03) \\
(0.84-1.31) \\
(0.67-1.10) \\
(0.64-1.01) \\
(0.80-1.06)\end{array}$ \\
\hline Total & 77 & $77 \cdot 7$ & 64 & $89.0^{*}$ & 56 & 50.6 & 125 & 125.8 & 634 & $674 \cdot 1$ & 0.94 & $(0.87-1.02)$ \\
\hline
\end{tabular}

${ }^{*} \mathrm{p}<0.05$.

Table 6 Observed $(O)$ and expected $(E)$ cases of selected types of cancer among 6494 employees at six ferroalloy plants, 1953-82, by occupational category

\begin{tabular}{|c|c|c|c|c|c|c|c|c|c|c|c|}
\hline \multirow{3}{*}{$\begin{array}{l}\text { Occupational } \\
\text { category }\end{array}$} & \multirow{3}{*}{$\begin{array}{l}\text { No } \\
\text { employed }\end{array}$} & \multicolumn{10}{|c|}{ Cancer site } \\
\hline & & \multicolumn{2}{|c|}{$\begin{array}{l}\text { Lung } \\
(I C D 162,163)\end{array}$} & \multicolumn{2}{|c|}{$\begin{array}{l}\text { Stomach } \\
\text { (ICD 151) }\end{array}$} & \multicolumn{2}{|c|}{$\begin{array}{l}\text { Colon } \\
\text { (ICD 153) }\end{array}$} & \multicolumn{2}{|c|}{$\begin{array}{l}\text { Prostate } \\
\text { (ICD 185) }\end{array}$} & \multicolumn{2}{|c|}{$\begin{array}{l}\text { All sites } \\
\text { (ICD 140-209) }\end{array}$} \\
\hline & & $O$ & $E$ & $O$ & $E$ & $O$ & $\boldsymbol{E}$ & $O$ & $E$ & $O$ & $E$ \\
\hline $\begin{array}{l}\text { Furnace } \\
\text { Maintenance, furnace } \\
\text { Maintenance, other } \\
\text { Quay, store, packing } \\
\text { Transport } \\
\text { Laboratory } \\
\text { Construction, various }\end{array}$ & $\begin{array}{r}2449 \\
219 \\
842 \\
797 \\
289 \\
143\end{array}$ & $\begin{array}{r}29 \\
1 \\
10 \\
7 \\
5 \\
1\end{array}$ & $\begin{array}{r}29 \cdot 6 \\
2 \cdot 8 \\
7 \cdot 3 \\
11 \cdot 1 \\
3 \cdot 5 \\
0 \cdot 9\end{array}$ & $\begin{array}{r}25 \\
3 \\
4 \\
14 \\
2 \\
1\end{array}$ & $\begin{array}{r}34 \cdot 0 \\
3 \cdot 0 \\
8 \cdot 6 \\
12 \cdot 6 \\
4 \cdot 0 \\
1 \cdot 0\end{array}$ & $\begin{array}{r}21 \\
2 \\
9 \\
10 \\
1 \\
1\end{array}$ & $\begin{array}{r}19 \cdot 1 \\
1.7 \\
4 \cdot 8 \\
9 \cdot 0 \\
1.6 \\
0.6\end{array}$ & $\begin{array}{r}47 \\
0 \\
14 \\
23 \\
9 \\
2\end{array}$ & $\begin{array}{r}47 \cdot 9 \\
3 \cdot 9 \\
11 \cdot 2 \\
18 \cdot 7 \\
6 \cdot 1 \\
1 \cdot 3\end{array}$ & $\begin{array}{r}241 \\
13 \\
67 \\
88 \\
28 \\
10\end{array}$ & $\begin{array}{r}255 \cdot 4 \\
23 \cdot 6 \\
64 \cdot 0 \\
96 \cdot 2 \\
31 \cdot 4 \\
8.0\end{array}$ \\
\hline $\begin{array}{l}\text { jobs } \\
\text { Anode paste plant } \\
\text { Office, administration } \\
\text { Unspecified }\end{array}$ & $\begin{array}{l}954 \\
117 \\
467 \\
217\end{array}$ & $\begin{array}{r}13 \\
3 \\
2 \\
6\end{array}$ & $\begin{array}{r}13 \cdot 0 \\
1.4 \\
4 \cdot 9 \\
3 \cdot 2\end{array}$ & $\begin{array}{r}10 \\
0 \\
4 \\
1\end{array}$ & $\begin{array}{r}15 \cdot 2 \\
1 \cdot 5 \\
5 \cdot 8 \\
3 \cdot 3\end{array}$ & $\begin{array}{r}10 \\
0 \\
1 \\
1\end{array}$ & $\begin{array}{l}8 \cdot 6 \\
0 \\
3 \cdot 3 \\
1 \cdot 9\end{array}$ & $\begin{array}{r}18 \\
1 \\
9 \\
2\end{array}$ & $\begin{array}{r}22 \cdot 2 \\
2 \cdot 1 \\
7 \cdot 9 \\
4 \cdot 5\end{array}$ & $\begin{array}{r}107 \\
13 \\
43 \\
24\end{array}$ & $\begin{array}{r}113.9 \\
11 \cdot 7 \\
43.5 \\
26.4\end{array}$ \\
\hline
\end{tabular}

*p $<0.05$.

was statistically significant. There were 77 cases of lung cancer in the total cohort versus 77.7 expected $($ SIR $=0.99)$. The only statistically significant SIR observed was for stomach cancer, which was lower than expected (SIR $=0.72)$.

When considering some selected cancers in the respective plant subcohorts, there was an excess of lung cancer $(O / E=17 / 9 \cdot 7)$ and cancer of the prostate $(\mathrm{O} / \mathrm{E}=20 / 12 \cdot 8)$ among employees at one of the ferrosilicon plants (plant A) and of colonic cancer $(\mathrm{O} / \mathrm{E}=11 / 5 \cdot 8)$ at plant $\mathrm{C}$, where ferrosilicon and calcium carbide have been produced (table 5). All these findings are of borderline statistical significance. The distribution of selected cancers by 
Table 7 Incidence of cancer at selected sites among employees at six ferroalloy plants, 1953-82, according to duration of employment. (Observed (O) number of new cases and SIR)

\begin{tabular}{|c|c|c|c|c|c|c|c|c|c|c|}
\hline \multirow[t]{3}{*}{ Cancer site } & \multicolumn{10}{|c|}{ Years employed } \\
\hline & \multicolumn{2}{|c|}{$1 \cdot 5-4$} & \multicolumn{2}{|c|}{$5-14$} & \multicolumn{2}{|c|}{$15-24$} & \multicolumn{2}{|c|}{$\geqslant 25$} & \multicolumn{2}{|c|}{ Total } \\
\hline & $O$ & $S I R$ & $O$ & $S I R$ & $O$ & $S I R$ & $O$ & $S I R$ & $O$ & SIR \\
\hline $\begin{array}{l}\text { Lung (ICD 162, 163) } \\
\text { Stomach (ICD 151) } \\
\text { Colon (ICD 153) } \\
\text { Prostate (ICD 185) } \\
\text { Cancer, all sites (ICD 140-209) }\end{array}$ & $\begin{array}{r}20 \\
9 \\
8 \\
12 \\
111\end{array}$ & $\begin{array}{l}1 \cdot 16 \\
0.52 \\
0.78 \\
0.54 \\
0.79\end{array}$ & $\begin{array}{r}17 \\
16 \\
15 \\
22 \\
150\end{array}$ & $\begin{array}{l}0.89 \\
0.78 \\
1.26 \\
0.79 \\
0.93\end{array}$ & $\begin{array}{r}12 \\
10 \\
12 \\
27 \\
121\end{array}$ & $\begin{array}{l}0.83 \\
0.62 \\
1 \cdot 28 \\
1 \cdot 16 \\
0.98\end{array}$ & $\begin{array}{r}28 \\
29 \\
21 \\
64 \\
252\end{array}$ & $\begin{array}{l}0.98 \\
0.80 \\
1.02 \\
1.07 \\
0.94\end{array}$ & $\begin{array}{r}77 \\
64 \\
56 \\
125 \\
634\end{array}$ & $\begin{array}{l}0.99 \\
0.72 \\
1.11 \\
0.99 \\
0.94\end{array}$ \\
\hline
\end{tabular}

Table 8 Observed $(O)$ and expected $(E)$ cases of lung cancer among employees at plant A, by occupational category

\begin{tabular}{|c|c|c|c|c|}
\hline Occupational category & Observed & Expected & SIR & Years employed \\
\hline $\begin{array}{l}\text { Furnace } \\
\text { Maintenance } \\
\text { Quay, store, packing } \\
\text { Transport } \\
\text { Anode paste plant } \\
\text { Various jobs } \\
\text { Office, administration }\end{array}$ & $\begin{array}{l}5 \\
1 \\
1 \\
3 \\
3 \\
2 \\
2\end{array}$ & $\begin{array}{l}2 \cdot 7 \\
1 \cdot 8 \\
0 \cdot 8 \\
1 \cdot 3 \\
1 \cdot 1 \\
0 \cdot 8 \\
1 \cdot 2\end{array}$ & $\begin{array}{l}1 \cdot 85 \\
- \\
2 \cdot 31 \\
2 \cdot 72 \\
2 \cdot 50 \\
1 \cdot 67\end{array}$ & $\begin{array}{l}03,05,06,12,18 \\
12 \\
25 \\
03,03,04 \\
13,19,38 \\
03,15 \\
21,22\end{array}$ \\
\hline Total & 17 & 9.7 & $1.75^{*}$ & \\
\hline
\end{tabular}

*95\% confidence interval: $1 \cdot 0-2 \cdot 8$.

Table 9 Total mortality and incidence of cancer, all sites (ICD 140-209), among employees at six ferroalloy plants, 1953-82, according to period of entry

\begin{tabular}{|c|c|c|c|c|c|c|}
\hline \multirow[t]{2}{*}{ Period of entry } & \multicolumn{3}{|c|}{ No of deaths, all causes } & \multicolumn{3}{|c|}{ Cancer, all sites (ICD 140-209) } \\
\hline & Observed & Expected & $S M R$ & Observed & Expected & $S I R$ \\
\hline $\begin{array}{l}1910-29 \\
1930-39 \\
1940-49 \\
1950-59 \\
1960-69\end{array}$ & $\begin{array}{l}738 \\
251 \\
432 \\
363 \\
151\end{array}$ & $\begin{array}{l}826 \cdot 8 \\
227.9 \\
475 \cdot 7 \\
410.4 \\
159.5\end{array}$ & $\begin{array}{l}0.89 \\
0.90 \\
0.91 \\
0.89 \\
0.95\end{array}$ & $\begin{array}{r}208 \\
101 \\
149 \\
132 \\
44\end{array}$ & $\begin{array}{r}228 \cdot 0 \\
93 \cdot 1 \\
157 \cdot 4 \\
137 \cdot 4 \\
58 \cdot 2\end{array}$ & $\begin{array}{l}0.91 \\
1.08 \\
0.95 \\
0.96 \\
0.76\end{array}$ \\
\hline Total & 1935 & $2150 \cdot 3$ & 0.90 & 634 & $674 \cdot 1$ & 0.94 \\
\hline
\end{tabular}

occupational category is summarised in table 6 . There was no excess of lung cancer among furnace workers or maintenance workers. Among workers at the anode paste plants, which implies definite exposure to PAH, there were three observed cases of lung cancer against 1.4 expected. The small number of men in several of the occupational categories, however, prevents any useful interpretation of many of the numbers given for the separate cancer sites.

Table 7 shows the SIRs for selected cancer sites according to cumulative employment time. For lung cancer, the highest SIR was observed among those with the shortest employment time (SIR $=1 \cdot 16)$, whereas for the other cancer sites the lowest SIRs were observed in this group. No obvious dose response relation, however, was observed for any of the cancer sites.

The observed excess of lung cancer at plant $\mathrm{A}$
$(\mathrm{SIR}=1 \cdot 75)$ was related to several occupational categories (table 8). There were five cases of lung cancer among the furnace workers versus $2 \cdot 7$ expected. The three cases of lung cancer among the anode paste plant workers $(1 \cdot 1$ expected) were all from plant $A$, and all of them were long term employees. There was no definite increase in SIR for lung cancer with employment time in this subcohort (not shown in the table).

Table 9 shows the total mortality and incidence of all cancers according to year of first employment. There was no trend in SMR or SIR from the older to the more recent employment periods. When the material was further stratified according to both period of entry and years since first employment, the highest SIRs for cancers of the lung, stomach, and colon were seen for the follow up period 25-34 years, and in particular among those employed before 1950 (table 10). 
Table 10 Incidence of cancer at selected sites among employees at six ferroalloy plants, 1953-82, according to period of entry and years since first employment. (Observed number of cases $(O)$ and $S I R$ )

\begin{tabular}{|c|c|c|c|c|c|c|c|c|c|c|c|}
\hline \multirow[t]{3}{*}{ Cancer site } & \multirow[t]{3}{*}{ Period of entry } & \multicolumn{10}{|c|}{ Years since first employment } \\
\hline & & \multicolumn{2}{|c|}{$1 \cdot 5-14$} & \multicolumn{2}{|c|}{$15-24$} & \multicolumn{2}{|c|}{$25-34$} & \multicolumn{2}{|c|}{$\geqslant 35$} & \multicolumn{2}{|c|}{ Total } \\
\hline & & $O$ & $S I R$ & $O$ & $S I R$ & $O$ & $S I R$ & $O$ & SIR & $O$ & $S I R$ \\
\hline \multirow[t]{2}{*}{ Lung } & $\begin{array}{l}1910-29 \\
1930-39 \\
1940-49 \\
1950-59 \\
1960-69\end{array}$ & $\begin{array}{l}3 \\
7\end{array}$ & $\begin{array}{l}0.71 \\
1.35\end{array}$ & $\begin{array}{l}1 \\
2 \\
8 \\
3\end{array}$ & $\begin{array}{l}2.78 \\
0.61 \\
0.94 \\
1.06\end{array}$ & $\begin{array}{r}4 \\
2 \\
12 \\
5\end{array}$ & $\begin{array}{l}3.48 \\
1.33 \\
1.33 \\
1.01\end{array}$ & $\begin{array}{r}15 \\
11 \\
4\end{array}$ & $\begin{array}{l}0.82 \\
1.16 \\
0.52\end{array}$ & $\begin{array}{l}19 \\
14 \\
18 \\
16 \\
10\end{array}$ & $\begin{array}{l}0.97 \\
1.23 \\
0.87 \\
0.90 \\
1.21\end{array}$ \\
\hline & Total & 10 & 0.98 & 14 & 0.93 & 23 & $1 \cdot 38$ & 30 & 0.84 & 77 & 0.99 \\
\hline \multirow[t]{2}{*}{ Stomach } & $\begin{array}{l}1910-29 \\
1930-39 \\
1940-49 \\
1950-59 \\
1960-69\end{array}$ & $\begin{array}{l}2 \\
4\end{array}$ & $\begin{array}{l}0.99 \\
0.67\end{array}$ & $\begin{array}{l}3 \\
4 \\
1\end{array}$ & $\begin{array}{l}0.68 \\
0.61 \\
0.61\end{array}$ & $\begin{array}{l}2 \\
4 \\
9 \\
3\end{array}$ & $\begin{array}{l}0.59 \\
1.74 \\
1.26 \\
0.95\end{array}$ & $\begin{array}{r}20 \\
9 \\
3\end{array}$ & $\begin{array}{l}0.62 \\
1.03 \\
0.52\end{array}$ & $\begin{array}{r}22 \\
13 \\
17 \\
11 \\
1\end{array}$ & $\begin{array}{l}0.62 \\
1.09 \\
0.87 \\
0.70 \\
0.18\end{array}$ \\
\hline & Total & 6 & 0.50 & 8 & 0.59 & 18 & $1 \cdot 12$ & 32 & 0.68 & 64 & 0.72 \\
\hline \multirow[t]{2}{*}{ Colon } & $\begin{array}{l}1910-29 \\
1930-39 \\
1940-49 \\
1950-59 \\
1960-69\end{array}$ & $\begin{array}{l}1 \\
2 \\
1\end{array}$ & $\begin{array}{l}1.70 \\
0.83 \\
0.36\end{array}$ & $\begin{array}{l}5 \\
5 \\
1\end{array}$ & $\begin{array}{l}2.51 \\
1.02 \\
0.65\end{array}$ & $\begin{array}{l}3 \\
1 \\
8 \\
3\end{array}$ & $\begin{array}{l}3.70 \\
1.10 \\
1.60 \\
1.05\end{array}$ & $\begin{array}{r}14 \\
8 \\
4\end{array}$ & $\begin{array}{l}0.86 \\
1.41 \\
0.95\end{array}$ & $\begin{array}{r}17 \\
9 \\
18 \\
10 \\
2\end{array}$ & $\begin{array}{l}0.99 \\
1.32 \\
1.53 \\
0.99 \\
0.47\end{array}$ \\
\hline & Total & 4 & $0 \cdot 70$ & 11 & $1 \cdot 28$ & 15 & $1 \cdot 57$ & 26 & 0.99 & 56 & $1 \cdot 12$ \\
\hline \multirow[t]{2}{*}{ Prostate } & $\begin{array}{l}1910-29 \\
1930-39 \\
1940-49 \\
1950-59 \\
1960-69\end{array}$ & $\begin{array}{l}5 \\
2\end{array}$ & $\begin{array}{l}1.23 \\
0.43\end{array}$ & $\begin{array}{r}1 \\
5 \\
14 \\
1\end{array}$ & $\begin{array}{l}2 \cdot 70 \\
1 \cdot 22 \\
1 \cdot 29 \\
0.37\end{array}$ & $\begin{array}{l}3 \\
1 \\
9 \\
7\end{array}$ & $\begin{array}{l}1.94 \\
0.47 \\
0.81 \\
1.19\end{array}$ & $\begin{array}{r}53 \\
21 \\
2 \\
1\end{array}$ & $\begin{array}{l}1.00 \\
1.39 \\
0.22\end{array}$ & $\begin{array}{r}56 \\
23 \\
16 \\
26 \\
4\end{array}$ & $\begin{array}{l}1.02 \\
1.30 \\
0.64 \\
1.25 \\
0.54\end{array}$ \\
\hline & Total & 7 & 0.73 & 21 & $1 \cdot 16$ & 20 & 0.95 & 77 & 1.00 & 125 & 0.99 \\
\hline
\end{tabular}

Table 11 Deaths from all causes, and incidence of all cancer and lung cancer among a selected group of 2025 short term employees (< 18 months), employed before 1 January 1970 at five of the plants)

\begin{tabular}{lllll}
\hline & Observed & Expected & SMR-SIR & $95 \%$ CI \\
\hline Total mortality & 367 & $341 \cdot 6$ & 1.07 & $(0.97-1 \cdot 18)$ \\
Cancer, all sites & 118 & 114.5 & 1.03 & $(0.86-1 \cdot 23)$ \\
Lung cancer & 27 & 14.8 & $1.82^{*}$ & $(1 \cdot 20-2.65)$ \\
Lung cancer, plant D & 9 & 1.9 & $4.66^{* *}$ & $(2 \cdot 17-8.99)$ \\
\hline
\end{tabular}

${ }^{*} \mathrm{p}<0.05,{ }^{* *} \mathrm{p}<0.01$.

For the latest follow up period ( $\geqslant 35$ years), the SIRs decreased considerably. There was no selective excess of lung cancer among workers at plant $\mathrm{A}$ in any of the follow up periods.

During the planning of the study an internal reference series consisting of workers from all plants with less than 1.5 years of employment was established. Table 11 shows the overall mortality and incidence of all cancers and lung cancer. The observed excess of lung cancer in this group (SIR $=1.82$ ) was most pronounced among employees at one of the ferromanganese plants (plant $D$ ), where nine cases of lung cancer were observed against 1.9 cases expected $(\mathrm{SIR}=4 \cdot 66)$. This result may indicate the presence of selection bias in the group, therefore they were not further used as an alternative reference series.

\section{Discussion}

The validity of the present results depends on several conditions. Firstly, the incidence of cancer in the present cohort has been studied on the basis of retrospective experience. The possibility that previous occurrence of cancer and death could have had a bearing on the likelihood of becoming a member of the cohort must therefore be considered. In this study 742 subjects, representing $6 \%$ of the original cohort, were not identified by a personal identification number and were thereby lost for follow up. If there is an excess of deaths and cases of cancer in this group compared with the remaining cohort the mortality and incidence of cancer in the ultimate cohort may have been underestimated. Such outcome dependent cohort admissibility represents a serious threat to studies based on retrospective experience.

The possibility of a selective loss of cases of cancer in the present cohort seems highly unlikely, although a selective loss of deaths cannot be completely ruled out. Of those lost to follow up, 282 were employed less than 1.5 years, which implies that the loss of "rel- 
evant" persons in relation to occupational cancer is less than indicated in table 2 . The unidentified workers were evenly distributed among the subcohorts, indicating that no particular loss from one or a few of the subcohorts had taken place. For the subcohort from plants $C$ and $D$ there was initially some doubt as to the completeness of the oldest cohort segments. Tentative exclusion of these segments gave lower SMRs, which does not support the possibility of a selective loss of deaths in this group, but rather reflects the "active worker effect" as the main ingredient of the healthy worker effect. ${ }^{15}$ The observed deficit in overall mortality (SMR $=0.90)$ and incidence of cancer (SIR $=0.94$ ) is not greater than what might be expected owing to the positive health selection of industrial workers that may be reflected in studies of this design. Furthermore, as five of the six subcohorts have been formed as inception cohorts (table 1), a mainly primary healthy worker effect could have been operating in the cohort. ${ }^{1316}$ Any bias due to outcome selective cohort admissibility seems therefore to have been negligible in the present study.

Regarding previous studies of the incidence of cancer in the Scandinavian ferroalloy industry, Langård et al found seven cases of lung cancer ( $3 \cdot 1$ expected) among ferrochromium workers but no cases among ferrosilicon workers ( 2.8 expected). ${ }^{7}$ A study from a Swedish ferrochromium plant showed no excess of respiratory cancer $(\mathrm{O} / \mathrm{E}=5 / 7 \cdot 2)$, but two mesotheliomas were found among maintenance workers. ${ }^{8}$ In a small cohort of ferrosilicon/ferrovanadium workers there was one case of lung cancer versus $2 \cdot 7$ expected (J Alexander, Cairo conference). Thus so far there has been no indication of an increased risk of lung cancer associated with the production of ferroalloys other than ferrochromium.

Although the production of ferrosilicon and ferromanganese is associated with exposure to various particles and gases, only a few of these components are known to be carcinogenic. The most relevant exposure in relation to lung cancer in this study would seem to be exposure to asbestos and polycyclic aromatic hydrocarbons. Furnace workers and maintenance workers are the groups most likely to be exposed to these agents. There is no overall excess of lung cancer in these groups, nor in the subgroup of long term employees. The absence of a dose-response relation, however, is rather non-informative, as the employment period used in this study as an indicator of exposure time overlaps the follow up period. ${ }^{17}$

Considering the asbestos consumption in the plants, the observed normal incidence of lung cancer among furnace and maintenance workers might be somewhat surprising. The result might indicate that the asbestos exposure to the individual worker has been quite low, or just that the subgroup with relevant exposure is small and has not been properly identified. Two mesotheliomas occurred among the workers in the original cohort. One of these cases, however, had been employed for less than one year, and had had long lasting exposure to asbestos in another industry.

Based on the few measurements of PAH around the ferroalloy furnaces at two of the study plants, the individual furnace worker has been only sporadically exposed to PAH, presumably at a level below 10 $\mu \mathrm{g} / \mathrm{m}^{3}$, for most working operations. The exposure also seems to be lower than that reported from the Norwegian aluminium industry, which also uses the Söderberg electrode, and where a twofold excess of lung cancer has been observed. ${ }^{18}$

At one of the ferrosilicon plants (plant A) an excess of lung cancer was observed (17 cases observed against 9.7 expected). Five of these were found among furnace workers ( 2.66 expected). The production process at this plant is similar to that of the other ferrosilicon plants, but plant $\mathbf{A}$ has in addition an anode paste plant, which produces anode paste for the Söderberg electrodes for the whole industry. This production involves exposure to polycyclic aromatic hydrocarbons at levels in the range of $2-20 \mu \mathrm{g} / \mathrm{m}^{3}$ (KE Knudsen, personal communication). The occurrence of three cases of lung cancer among the anode paste workers $(1 \cdot 1$ expected) is therefore notable. Additional information from the plant and the relatives of the patients with cancer showed no other relevant occupational exposures among the 17 cases of lung cancer, except for two workers who had been employed at a neighbouring nickel refinery. They had worked six and seven years at the nickel refinery respectively, one within 10 years before the cancer diagnosis, the other intermittently five to 30 years before diagnosis. In regard to sinonasal cancer, two of the five cases observed in the cohort were from plant $\mathrm{A}$, and one of these had also been working at the nickel refinery. ${ }^{19}$

Information about smoking habits among the cohort members in earlier times is not known. In the period 1977-83, however, information on smoking status was obtained from a sample of present employees at four of the plants (table 12). If the slightly higher smoking prevalence observed in the factory workers in this period compared with the general population reflects past differences in smoking habits between the groups a modest increase in the incidence of lung cancer could be expected in the cohort because of this difference. ${ }^{20}$ The observed incidence of lung cancer in five of the subpopulations, however, does not support the suggestion of smoking as a confounder of importance in these subcohorts. As the smoking habits among employees at plant $\mathrm{A}$ seem to 
Cancer incidence among workers in the Norwegian ferroalloy industry

Table 12 Percentage daily smokers among employees at four of the plants in 1977-83, compared with the general male population*

\begin{tabular}{lllllll}
\hline Year & \multicolumn{2}{l}{ Study plants } & & & \multicolumn{2}{c}{ General male population (\% daily smokers) } \\
\cline { 2 - 3 } \cline { 6 - 7 } & Plant & No of employees & \% daily smokers & & Age 16-74 & Age 25-64 \\
\hline $1977-78$ & B,C,E & 631 & 52 & 45 & 47 \\
1983 & A & 577 & 47 & 42 & 46 \\
\hline
\end{tabular}

* Based on figures from the National Council on Smoking and Health.

have been similar to the rest of the cohort, it is less likely that the observed excess of lung cancer at plant A can be explained by more smoking in previous years among the employees in this subcohort. Occupational exposure factors might therefore have contributed to the observed excess of lung cancer among the workers at this plant.

The statistically significant deficit of stomach cancer in this cohort is consistent for all subcohorts (table 5 ), with SIRs ranging from 0.49 to 0.88 . A deficit of stomach cancer was also found among long term employed Swedish ferrochromium workers, ${ }^{8}$ whereas the incidence in the Norwegian ferrochromium cohort was as expected. ${ }^{7}$ As the ferroalloy plants, at least in previous years, must be considered as typically polluted workplaces, these findings are in contrast with previous observations of a relation between polluted workplaces and the development of stomach cancer $^{21}$ (C A Veys, paper at XXI International Congress on Occupational Health, Dublin, 1984). On the other hand, we are not aware of any occupational factors in this industry that could possibly prevent stomach cancer, and there is no relation between the observed cancer deficit and the duration of employment in this study (table 7). The regional variations in the incidence of cancer may explain the result to some extent, as the counties in which the study plants are located had a deficit of $9 \%$ of stomach cancer for the period 1972-6 compared with the national incidence. ${ }^{22} \mathrm{~A}$ possible exclusion from shiftwork of persons with gastric symptoms might also have contributed to the observed result.

The higher than expected incidence of colonic cancer in the subcohort at plant $C$ and of prostatic cancer in the subcohort at plant $\mathbf{A}$ is statistically of borderline significance, the $95 \%$ confidence intervals for both SIRs include unity. Although occupational factors may have contributed to this excess, the possibility of a type I error is also close at hand, bearing in mind the many independent comparisons performed in this study. ${ }^{23}$

In the case of renal cancer the previously reported excess among ferrosilicon/ferrovanadium workers $(\mathrm{O} / \mathrm{E}=4 / 0 \cdot 9)$ (J Alexander, Cairo conference) has not been confirmed in the present study (SIR $=0.90$ ).

As a potential excess mortality or morbidity from a certain disease can be hidden in the internal structure of a cohort, ${ }^{24}$ the material was stratified according to period of entry and period of follow up. Assuming an average latent period of 20-30 years for occupational cancers, the follow up period 25-35 years would be of particular interest in the present study. As the exposure to dust and fumes is assumed to have been higher in previous years, the observed excess of lung cancer $(O / E=18 / 11 \cdot 3)$ and of colonic cancer $(\mathrm{O} / \mathrm{E}=12 / 6 \cdot 7)$ among subjects employed before 1950 for the follow up period 25-34 years is notable. Neither of these SIRs is statistically significant, however, and a further interpretation of these results is hampered by small figures in each cell.

The choice of a proper reference population is always a matter of concern in cohort studies such as the present one. The inherent problems of using national figures for comparison are well known. We aimed therefore at forming an alternative reference group of short term employees, which somewhat surprisingly was found to have a significant excess of lung cancer $(S I R=1 \cdot 82)$. Further information showed a distinctive recruitment pattern of migrant workers to short term employment at several of the plants in the 1930s and 1940s, including subjects with a life style, and presumably also smoking habits, different from the general population. At plant $D$, where nine cases of lung cancer were observed (1.9 expected), most of the short term employees were seamen having short working periods on land. Seamen in Norway have smoked more and have been reported to have an extreme excess of lung cancer compared with the general population. ${ }^{25}$ This group was therefore not further used as a reference group.

Owing to the considerable regional variations of many cancers, ${ }^{22}$ the cancer incidence rates of the county in which each plant is located could also be an alternative reference entity. When using county rates for the incidence of lung cancer for 1972-6 as reference for the respective subcohorts, a change in SIR occurred for employees at plant $A$ from 1.75 to 1.58 (95\% CI: 0.92-2.51) and for employees at plant B from 0.69 to $1 \cdot 10$. There were only small adjustments for the other plants. Nevertheless, as other identified occupational groups with excess lung cancer might have contributed to the $11 \%$ excess lung cancer 
observed in the county where plant $A$ is located, ${ }^{19}$ the county figures for lung cancer in this study would not necessarily be more representative for an unexposed reference population than the national incidence rates.

In the light of the many non-positive results presented the statistical power of the study really to detect a true increase in the incidence of cancer should be considered. Given a type I error $(\alpha)=0.05$ and type II error $(\beta)=0 \cdot 20$, an expected figure of nine or more would have been required for each association studied to detect a twofold increase in the risk of cancer. ${ }^{26}$ Similarly, an expected figure of 32 or more would be necessary for detecting a $50 \%$ excess in the risk of cancer. This would imply that more than a twofold increase in the incidence of cancer for most of the cancers studied among the members of this cohort is unlikely. For rare cancer locations, however, or for cancer occurring in particular subgroups of the cohort, such an excess would not necessarily have been shown. The statistical power of the study must therefore be borne in mind when its non-positive results are evaluated.

This project has been financed by the Health Board of Norwegian Ferroalloy Industry. Unni Danielsen and Patricia Flor helped prepare this manuscript.

\section{References}

${ }^{1}$ Roberts WC. The ferroalloy industry. Hazards of the alloys and semimetallics: part I. J Occup Med 1965;7:30-6.

${ }^{2}$ Roberts WC. The ferroalloy industry. Hazards of the alloys and semimetallics: part II. J Occup Med 1965;7:71-7.

${ }^{3}$ Bruce T. The occurrence of silicosis in the manufacture of silicon alloys. J Ind Hyg Toxicol 1937;19:155-62.

${ }^{4}$ Broch C. An investigation of the occurrence of silicosis in a plant for fusing ferrosilicon and ferrochromium. Nord Hyg Tidskr 1949;1:1-7. (In Norwegian. English abstract. J Ind Hyg Toxicol 1949;31:97.)

${ }^{5}$ Tanaka S, Lieben J. Manganese poisoning and exposure in Pennsylvania. Arch Environ Health 1969;19:674-84.

${ }^{6}$ Cook DG, Brait KA. Chronic manganese intoxication. Arch Neurol 1974;30:59-64.

${ }^{7}$ Langård S, Andersen A, Gylseth B. Incidence of cancer among ferrochromium and ferrosilicon workers. $\mathrm{Br} J$ Ind $\mathrm{Med}$ 1980;37:114-20.

${ }^{8}$ Axelsson G, Rylander R, Schmidt A. Mortality and incidence of tumours among ferrochromium workers. $\mathrm{Br} \mathrm{J}$ Ind Med 1980;37:121-7.

${ }^{9}$ Dalgaard JB, Gregersen M. Risk of poisoning during transportation of ferrosilicon by ship. Nord Med 1964;71:271-3. (In Norwegian. English abstract.)

${ }^{10}$ Bjørseth A, Bjørseth O, Fjeldstad PE. Polycyclic aromatic hydrocarbons in the work atmosphere. II Determination in a coke plant. Scand J Work Environ Health 1978;4:224-36.

${ }^{11}$ Bjørseth A, Bjørseth O, Fjeldstad PE. Polycyclic aromatic hydrocarbons in the work atmosphere. I Determination in a aluminium reduction plant. Scand J Work Environ Health 1978; 4:212-23.

${ }^{12}$ Feinstein A. Clinical biostatistics. St Louis: CV Mosby, 1977:74-104.

${ }^{13}$ Weiss W. Heterogeneity in historical cohort studies: a source of bias in assessing lung cancer risk. J Occup Med 1983;25:290-4.

${ }^{14}$ Miettinen O. Estimability and estimation in case-referent studies. Am J Epidemiol 1976;103:226-35.

${ }^{15}$ Wen CP, Tsai SP, Gibson RL. Anatomy of the healthy worker effect: a critical review. J Occup Med 1983;25:283-9.

${ }^{16}$ Olsen J, Sabroe S. Researching occupational mortality: the problem of comparison. Scand J Soc Med 1979;7:1-6.

${ }^{17}$ Enterline PE. Pitfalls in epidemiological research: an examination of the asbestos literature. J Occup Med 1976;18:150-6.

${ }^{18}$ Andersen A, Dahlberg BE, Magnus K, Wannag A. Risk of cancer in the Norwegian aluminium industry. Int $J$ Cancer 1982;29:295-8.

${ }^{19}$ Pedersen E, Høgetveit AC, Andersen A. Cancer of respiratory organs among workers at a nickel refinery in Norway. Int Cancer 1973;12:32-41.

${ }^{20}$ Axelson $O$. Aspects on confounding in occupational health epidemiology. Scand J Work Environ Health 1978;4:85-9.

${ }^{21}$ Meyer MB, Luk GD, Sotelo JM, Cohen BH, Menkes HA Hypothesis: the role of the lung in stomach carcinogenesis. Am Rev Respir Dis 1980;121:887-92.

${ }^{22}$ Cancer Registry of Norway. Geographical variations in cancer incidence in Norway 1966-1975. Oslo: Landsforeningen mot Kreft. 1978.

${ }^{23}$ Dinman BD, Sussman NB. Uncertainty, risk, and the role of epidemiology in public policy development. $J$ Occup Med 1983;25:511-6.

${ }^{24}$ Koskela RS, Järvinen E, Kolari PJ. Effect of cohort definition and follow-up length on occupational mortality rates. Scand J Work Environ Health 1984;10:311-6.

${ }^{25}$ Baksaas I, Lund E, Skjerven JE, Langård S, Vellar OD, Aarø LE. Cancer among merchant seamen: a cohort study. Tidsskr Nor Laegeforen 1983;103:2317-20. (In Norwegian. English abstract.)

${ }^{26}$ Haines T, Shannon H. Sample size in occupational mortality stud ies. J Occup Med 1983;25:603-8. 